\title{
Changing Characteristics of a Significant Part of the Urban Fringe in Ankara: İmrahor Valley*
}

\author{
Ankara Kent Çeperinin Önemli Bir Parçasının Değişen Karakteri: \\ Imrahor Vadisi
}

\author{
Fulya SINACI ÖZFINDIK \\ Asst. Prof., Erciyes University, Department of City and Regional Planning, Kayseri, Turkey \\ fsinaci@erciyes.edu.tr \\ ORCID ID: 0000-0002-0239-9516
}

DOI: $10.5505 /$ jas.2019.21548

\begin{abstract}
İmrahor Valley, which covers a significant part of the urban fringe in Ankara, has a crucial role in conserving the ecological balance of city with its landscape and other natural features. The valley has long been considered as one of the most important ecological areas of the city and protecting the valley as part of green system has been a primary objective since the first plan of city. However, the valley has rapidly lost its natural characteristics under the effects of recent planning policies and implementations. This article investigates the changes in Imrahor Valley as a contemporary example of the transformations at the fringe of Ankara. The aim of this article is to analyze the changing process of the valley and to determine the factors affecting this process. In the light of previous literature, researches and interviews, it is seen that the plan revisions since the mid-2000s, market forces and speculative pressures have been the main drivers that increase the tension in the valley and pave the way for construction. The importance of greenbelt regulations, protective land policies and the plan decisions taking into account the upper-scale ecological systems are also emphasized in the article.
\end{abstract}

Keywords: Urban fringe, Urban growth, Greenbelt, İmrahor Valley, Ankara

\section{$\ddot{O} z$}

Ankara kent çeperinin önemli bir bölümünü kapsayan İmrahor Vadisi, peyzajı ve diğer doğal özellikleri ile kentin ekolojik dengesinin korunmasında kritik bir role sahiptir. Vadi uzun süredir kentin en önemli ekolojik alanlarından biri olarak kabul edilmiş ve vadiyi yeşil sistemin parçası olarak korumak kentin ilk planından itibaren öncelikli kararlardan olmuştur. Ancak, son dönem planlama politikalarının ve uygulamalarının etkisi ile vadinin doğal özelliklerini hızla kaybettiği görülmektedir. Makale, İmrahor Vadisinde meydana gelen değişimleri Ankara kent çeperinde gerçekleşen dönüşümlerin güncel bir örneği olarak araştırmaktadır. Makalenin amacı, vadinin değişen sürecini analiz etmek ve bu süreci etkileyen faktörleri tespit etmektir. Literatür araştırmastna ve alanda yapılan görüşmelere dayanılarak, 2000'li yılların ortasından itibaren uygulanan plan revizyonlarının, piyasa güçlerinin ve spekülatif baskıların vadideki gerilimleri artıran ve yoğun yapılaşmanın önünü açan esas nedenler olduğu ifade edilebilmektedir. Yeşil kuşak düzenlemelerinin, koruma odakl arazi politikalarının ve üst ölçekli ekolojik sistemleri dikkate alan plan yaklaşımlarının ve kararlarının önemi bu çalışmada ayrıca vurgulanmaktadır.

Anahtar sözcükler: Kent çeperi, Kentsel büyüme, Yeşil kuşak, İmrahor Vadisi, Ankara

* This article is based on a part of the PhD dissertation entitled "Growth Control on the Urban Fringe: Planning and Policy Instruments-The Case of Ankara", written under the supervision of Assoc. Prof. Bahar Gedikli of The Middle East Technical University Graduate School of Natural and Applied Sciences, City and Regional Planning Program.

** Bu makale, Orta Doğu Teknik Üniversitesi Fen Bilimleri Enstitüsü Şehir ve Bölge Planlama Anabilim Dalı’nda Doç. Dr. Bahar Gedikli danışmanlığında gerçekleştirilen "Growth Control at the Urban Fringe: Planning and Policy Instruments - The Case of Ankara" adlı doktora tezinin bir bölümüne dayandırılarak hazırlanmıştır. 


\section{Introduction}

Valley areas have unique characteristics with regard to the variety of climatic events, including temperature, moisture, fogging and insulation which occur within them. This is due to their morphological structure. Such areas provide natural drainage canals for water and important wind corridors, while playing an important role in preserving the ecological balance and preventing the loss of open space in urban and fringe areas. Green areas in valleys are also significant in terms of the climatic and visual aspects of their biological diversity (Öztan, Arslan, Perçin, Barış, Kurum, Şahin, 2001, p.19; Koç, 2006, p.1). The planning of valleys is crucial in this sense, as they are extremely important for cities as a part of a green system, as well as being suitable for recreational use. Protecting valleys should therefore be a priority in planning in order to improve environmental quality, provide options for recreation, and ensure the continuity of functional and aesthetic aspects.

Imrahor Valley is one of the most important parts of the valley system of Ankara, and has the features described above. Nevertheless, the valley is a contemporary example of the problems encountered at the city's fringe. Although the valley has been described as "a recreational area", "a green axis" and "a part of the greenbelt" since the city was first planned, the natural character of the valley has recently been dramatically damaged. The main reasons affecting the valley are examined in the article,

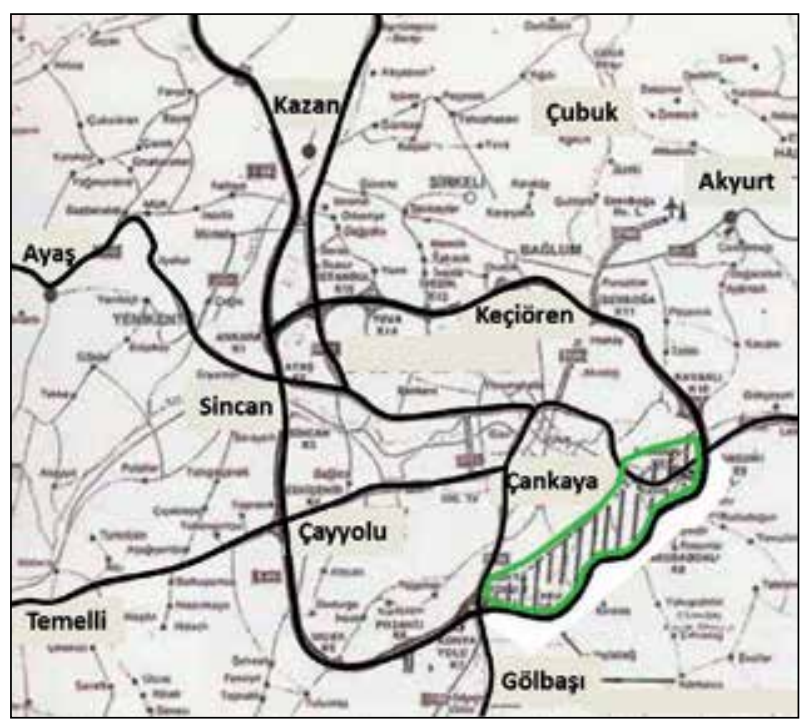

Figure 1. Location of İmrahor Valley.

Source: Mimarlar Odası Ankara Şubesi, 2015. which consists of an analysis of the literature, research of planning documents, planning notes, and reports specific to İmrahor Valley. There are also in-depth interviews with the headmen of Mühye village in the valley, as well as the former president of the Kavaklidere Solidarity and Beautification Association, who is the head of a working team that aims to protect İmrahor Valley. Following an explanation of the general features and the changing process of İmrahor Valley, many requirements are determined and proposals suggested to protect the valley in the context of urban planning.

\section{The General Features of İmrahor Valley}

The valley system in Ankara has quite a profound effect on the landscape. İmrahor Valley, one of the most important elements of this system, has an important role in shaping the form of the south east fringe of Ankara (Figure 1). The valley covers an area of approximately $3,526 \mathrm{ha}$, and is $8 \mathrm{~km}$ long and $300-400 \mathrm{~m}$ wide. The valley is actually a major part of an elevated water basin, starting with Salt lake in Central Anatolia and flowing into the Eymir and Mogan lakes to the south of Ankara (Öztan et.al, 2001). The topographical structure of the valley is comprised of a valley plain, slopes and ridges, which creates a wind corridor that has a positive impact on the microclimate of the city. The Sazlik (İmrahor) stream is also an important part of this natural structure as it enriches the valley landscape by passing through the valley and flowing into Eymir lake, (Figure 2). Although the stream bed runs dry

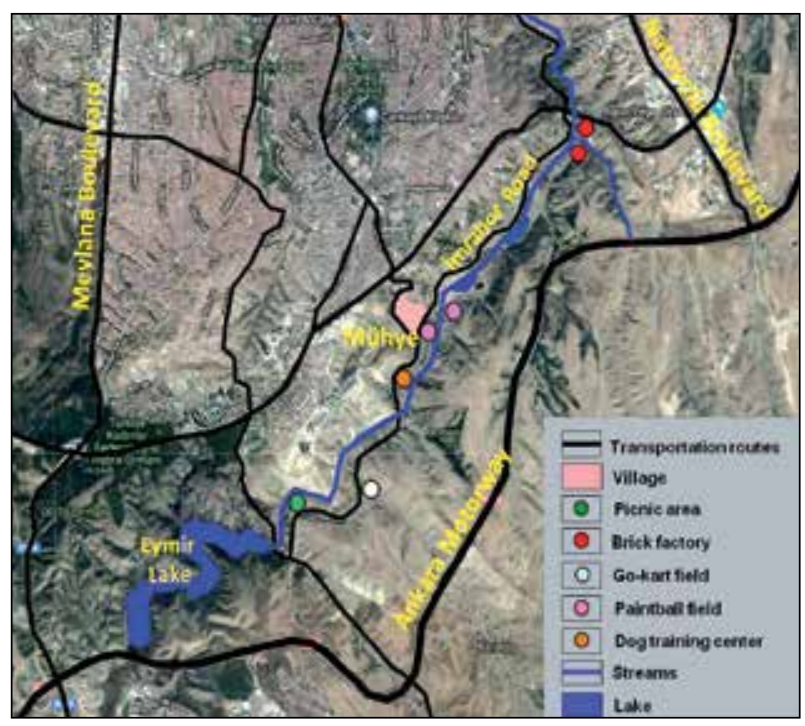

Figure 2. The topographic structure, transportation and land-uses of the valley.

Source: Drawn by the author over satellite image, 2019. 
for much of the year, the stream flows again after heavy rains. The natural vegetation in the valley includes a rich collection of herbaceous, shrub and tree species that was found to include 550 plants, 238 genera and 387 taxa belonging to 70 families (Şağban, 1998).

İmrahor Valley, which covers the largest part of the southeast of the fringe, is vital for the city. The area forms part of the watershed that feeds the water sources of Mogan and Eymir lakes and natural vegetation, while also acting as a wind corridor by providing air circulation to the city and providing areas for recreational use.

\section{Changes in İmrahor Valley}

İmrahor Valley has been recognized as a vital ecological area ever since Ankara was first conceived, and is considered a particularly important part of the greenbelt at the fringe. Jansen, who prepared the first spatial plan for Ankara in the early Republican Era, referred to Ankara as "the city of valleys" in the 1937 Ankara Development Plan. While the boundaries of the plan did not contain Imrahor Valley, Jansen defined the landscape of İncesu Valley in the plan report as follows ${ }^{1}$ (1937, p.26): "The land in the İncesu valley turns into a carpet of flowers for a short time in spring. The east of Yenişehir and the south of Cebeci cannot be compared with the other parts of city in terms of beauty". Jansen proposed the allocation of a green area consisting of natural features, green corridors, allotments and sports fields at the fringe. The plan was implemented between 1932 and 1938, however the implementations of the plan failed to provide a holistic and integrative framework for the fringe area.

The Yücel-Uybadin Plan aimed to keep the development within the topographic bowl, with İmrahor Valley and Eymir lake designated as the southern boundary of the plan where development was not recommended. The plan led to the density of the city increasing. Efforts to manage the sprawl failed, leading the city to spread outside the topographic bowl and the continued growth of unplanned areas at the fringe. The Mamak-ÜreğilKayas axis was the site of one of the most intensive unplanned settlement areas at the north of İmrahor Valley outside its borders.

The characteristics of the valley in the early 1970s were described as follows by the headman of a village in the valley in an interview: "People worked in agriculture with their own lands. The economic income of the people living in the valley came from brick kilns, agriculture and husbandry. There were 25 brick kilns in the valley which employed many villagers. Besides this, off-roads were held and places for selling flowers were located in the valley. Even wardens used to be employed in the valley". During those years, Ankara Metropolitan Planning Office (AMPB) prepared the 1990 Ankara Metropolitan Plan, which was the first comprehensive master planning effort to include the Imrahor Valley. The AMPB conducted years of research to determine the areas suitable for settlement. An area extending to a radius of around $50 \mathrm{~km}$ surrounding the city in terms of the topography, potential of the land, geology, geomorphology, hydrology, climate, landscape, archeology, ecology, rural settlements and the development characteristics of the city were investigated, in which many surveys and threshold analyses were conducted and a comprehensive land-use map was drawn up prior to the creation of alternative schemes. In the 1990 plan, the objectives for valleys of the city were as follows (Ankara Metropoliten Alan Nazım Plan Bürosu, 1977):

- avoiding increases to urban density and the generation of a greenbelt

- the consideration of the İmrahor Valley, Gölbaşı and the Bayındır Dam as parts of a system

- the preparation of plans to conserve recreation areas at the fringe

- the creation of recreational areas between the Eskişehir Highway, Çayyolu and Konya Highway to restrict urban development, and

- the protection of the valleys as wind corridors.

The idea of having a greenbelt was one of the most important proposals of the 1990 Plan. According to the literature, the aims of a greenbelt are to provide environmental benefits and support for recreational opportunities while preventing urban sprawl (Department for Communities and Local Government, 2006, World Bank, 2008, Zhao, Bin Lu and Woltjer, 2009, Cadieux, Taylor and Bunce, 2013, Jinjun, 2012). In accordance with these aims, a greenbelt around Ankara was proposed to protect the

1 İncesu stream passes through Ulus, Cebeci, İmrahor Valley and flows into Mogan lake. As the İmrahor Valley is on the route of İncesu Stream, many documents accept that the description of İncesu Valley by Jansen in the plan report is also valid for İmrahor Valley. 
natural structure of the valley, prevent development at the fringe, consider the valley as being part of a green system, increase recreational areas, reduce air pollution, and protect the city from floods. The plan shows İmrahor Valley, Eymir and Mogan lakes connected to urban green areas, thus forming a continuous green corridor. The Çubuk, Hatip and İmrahor stream basins were also proposed as components of a green system for the city, and were later forested as part of the Greenbelt Forestation Project, as explained below.

In accordance with the 1990 Plan, the Ministry of Forestry General Directorate of Forestation and Erosion Control began implementation of the Ankara Greenbelt Forestation Project in 1983. Forestation was considered in three sub-zones (Tekeli, Altaban, Güvenç, Türel, Günay and Bademli, 1986, p. 55): The first greenbelt proposal started in the south of Ankara at Atatürk Forest Farm and continued through the forested area of Middle East Technical University (METU) incorporating the Eymir and Mogan lakes, the water reservoir basins, and İmrahor Valley, before passing Hüseyin Gazi Mountain, Çubuk Dam lake, Bağlum, İvedik, some parts of Macunköy, and ending again in Atatürk Forest Farm. A second belt was proposed as a continuation of the first belt, and comprised of Bayındır Dam lake, Nenek, Tatlar, Mahmudiye and some parts of Susuz village, Sincan, Osmaniye, Elvan, Bağlica and Alacaatl. The third greenbelt proposal encompassed Elmadağ, Hasanoğlan, Kırıkkale, Kurtboğazı Dam lake and its environs, as well as the slopes of Kizllcahamam and some parts of Haymana and Beynam Forest. The greenbelt forestation project of the AMPB covered an area of 24,408 ha, and was one of the most important initiatives of the ministry in terms of property transfer at the fringe, with all unclaimed and unregistered lands being transferred to the Ministry of Agriculture and Forestry for forestation (Tekeli, 1986, p. 96).

Forestation initiatives continued until 1997, although the process of implementation was criticized due to its scope. The actual amount of ecological replenishment was limited to the planting of trees in the city and at the fringe. While this may have contributed to the natural structure of city, the greenbelt was not used as a "planning tool", in that it failed to include and integrate agricultural areas, valleys and water surfaces, as well as natural conservation and recreational areas. Instead, the overall forestation project was implemented in a fragmented and disconnected manner, with the greenbelt plantations having almost no relation with other open and green spaces in the metropolitan area. As a result, the idea of creating a green system could not be realized, and as an additional blow, insufficient funding was sourced for the forestation activities of the Ministry of Agriculture and Forestry (Çulcuoğlu, 1997, p.109).

Despite the conservation priorities of the 1990 Plan, and the significant quantities of land accumulated by public authorities, there was, according to Tekeli (1986), a lack of efficient land policies. As a result, the first residential development occurred as unplanned settlements in the southwest of the valley in the 1980s, with people constructing unauthorized housing and dairies on their own lands (interview with a headman, December 2015).

The greenbelt policy was also a priority of the Ankara Development Plan 2015, which was prepared in 1985 within the context of the Ankara Transportation Master Plan by a team from METU. In order to ensure the desired effect on the microclimate, the width of the greenbelt system in the previous plan was increased to $8-10 \mathrm{~km}$, the idea being to protect all environmental aspects as a whole. The objectives set for the valleys were:

- to accelerate greenbelt implementations in the metropolitan area,

- to protect the İmrahor-Mogan watersheds, and

- to create large parks in the city and at the fringe.

İmrahor Valley was considered to be an important part of green system in the 2015 Plan, and while the plan failed to gain approval and be converted into a legal document, it did showed the continuity of the greenbelt decision at the fringe in terms of being an upper-scale strategy.

In 1988, as the forestation of İmrahor Valley continued, the Doğukent Project, was applied outside the boundaries of the valley to the southeast. The project was approved by the Ankara Metropolitan Municipality in 1991, with the aim being to direct urban growth in an easterly direction. Residential uses, recreation areas and other urban services are included the project, and while it has yet to be realized, the project encourages development in a fragmented manner and is a cause of urban sprawl along the side of İmrahor Valley.

Ankara Forestation Master Plan (AKAP) was designed and approved in 1990 as a complementary plan to the Ankara Greenbelt Forestation Project (1983), and aimed to plant 500 ha of trees over four years to achieve the following objectives (Çulcuoğlu, 1997, p. 88): The creation of passive green areas through the forestation of valleys, the environs of highways and railways at the fringe, and 
in the roads and streets of the city. Another aim was to create active green areas through the forestation of parks, green fields, school gardens and housing gardens. The Forestation Master Plan was implemented by the Ankara Metropolitan Municipality, and saw some parts of İmrahor Valley, Pursaklar, Eymir lake and its environs, the Çubuk I, II and Bayındır Dams and Hacıkadın Valley all being forested in the mid-1990s.

The importance of the valleys in Ankara was also emphasized in the Ankara Development Plan Scheme of 2025, which was prepared in the early 1990s, but not implemented. The valleys were set aside for the recreational needs of the city, and İmrahor Valley was highlighted as being the most important part of the metropolitan area recreation system. The plan aimed to create a green axis that would permit the creation of multi-purpose recreation environments, thus integrating Atatürk Forest Farm, İmrahor Valley, and Mogan and Eymir lakes into each other. The objectives of the plan related to the valley were to protect the natural character of the valleys, consider the valleys as being part of the greenbelt and wind corridors, create new green areas by protecting stream beds and water resources, design recreation areas and remove the sand quarries and brick kilns from İmrahor Valley.

İmrahor Valley was a significant factor in the recreation projects of the Ankara Metropolitan Municipality, which was the result of the planning efforts of the 1990s (Çulcuoğlu, 1997, p. 88). Accordingly, a 1/5000 scale İmrahor Valley Recreation Area Master Plan was prepared by the Municipality in 1992. This plan aimed to conserve the Valley's natural identity, and was the first specific plan for the Valley. The targets of the plan were to open up the valley plain for recreational use and low-density construction, modernize the characteristics of villages, remove the brick kilns and transfer them to another location in the city, and open up the forest areas for recreational use. In the plan, green areas were protected as a part of an open system, and a large park was created in the valley plain, while social and commercial centers, residential areas, and commercial recreation areas of limited size were proposed. The plan proposals and implementations were widely criticized. The criticisms highlight the importance of the valley for Ankara, and note that the Master Plan did not meet the real needs of the city but was designed with the aim of stopping speculative demand and illegal constructions in the valley (Bademli, 2002, p.2; İmrahor Vadisi Doğal Sit Alanı Önerisi Açıllama Raporu, 2002, p. 3).
In the same year that the approval of the Master Plan was granted, Gölbaşı and its environs to the south of İmrahor Valley were declared a "Specially Protected Area". The aim of this move was to protect Mogan and Eymir lakes, as well as the watersheds and the reaches feeding the lakes, while meeting the recreational needs of the city (İmrahor Vadisi Doğal Sit Alanı Önerisi Açıklama Raporu, 2002, p. 13). A 1/25000-scale Gölbaşı Specially Protected Area Plan was prepared by the Institute of Specially Protected Areas in 1992. The plan covered a $245 \mathrm{~km}^{2}$ area $20 \mathrm{~km}$ from the city center that contained 10 villages, Mogan and Eymir lakes and a part of İmrahor Valley.

In the mid-1990s, İmrahor Valley was home to villages, unplanned settlements, brick kilns and factories (Figure 3). Şağban $(1998$, p.5) indicates that the brick factories began to disappear from the valley in the 1990s, and the headman of a village in the valley explains that this was the start of a period of economic difficulties for local villages. The closure of the factories increased unemployment, and there was also less employment in gardening and farming, largely due to damage being caused to gardens through excavations in the valley (December, 2015).

The year 2002 was significant in terms of the efforts to protect Imrahor Valley. A working team was created that year of members from the Kavaklidere Solidarity and Beautification Association, as well as the Mamak Mass Organizations Platform, along with professionals from the Chambers of Architects, Landscape Architects, City Planners and Environmental Engineers and academics from Ankara University, Bilkent University, Middle East Technical University and Gazi University. The team was tasked with highlighting the ecological characteristics of the valley. Many seminars, weekly meetings and trips were arranged, and there were two important meetings

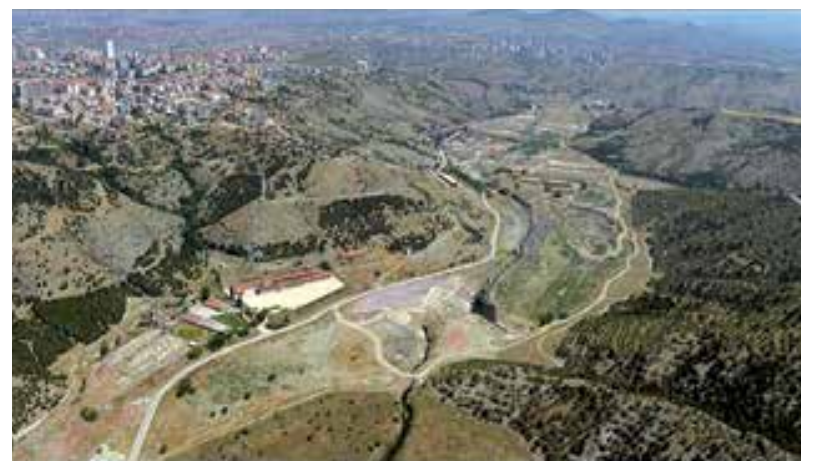

Figure 3. General view of İmrahor Valley in the late 1990s. Source: İmrahor Vadisi, 2015. 
realized in 2002 under the titles "The Present and the Future of İmrahor Valley" and "İmrahor Valley Activities". A symposium was organized, exhibitions were staged, trees were planted on the sidelines of the meetings, and implementations were covered in both the visual and written media. At the end of the meetings, the İmrahor Valley Explanation Report was prepared as a base report which emphasized the ecological significance of the valley and explained the motivations for its protection. Based on this report, an application was made to the Cultural and Natural Heritage Preservation Board of the Ministry of Culture, which aimed to have the valley registered as a "Natural Preservation Site" to prevent its ecological destruction. Following the application, the area containing Mogan and Eymir lakes was registered as a "Specially Protected Environmental Area", although only a minor part of İmrahor Valley was included in the protected area (interview with the former president of the Kavaklidere SBA, November, 2015).

Another project application was presented to the European Commission Program for Local Civil Initiatives Micro Projects. This application was for a more permanent and comprehensive project which intended to integrate the valley with the city, thus raising the quality of life in the villages of the valley by providing a local organizational structure, while not affecting their character. The former president of Kavaklidere SBA stated that (interview in November, 2015): "Protecting and creating rural life at the fringe and the participation of these villages in urban life, without damaging the ecological characteristics of the valley, were the main objectives of the project". However, the project proposal was rejected by the European Commission Program.

The president of the Kavaklidere SBA interpreted the results of the efforts to protect İmrahor Valley as follows (interview in November, 2015):

"The efforts inspired many studies of İmrahor Valley, and the number of people working on this issue increased. These project development processes were successful in terms of fostering collaboration among different parties in the framework of conservation. In addition, the attempts experienced in İmrahor could serve as an informative example, not only for the natural environment in Ankara, but also for other metropolitan fringes. As a consequence of the rejection of the year-long efforts related to İmrahor Valley and the mentality of the government, the motivation of the working team took a significant hit, and the work remained at a theoretical academic level. The team dispersed, with many switching their focus towards the Atatürk Forest Farm conservation efforts. However, the analysis and report prepared by the working team formed the basis and served as a guide for ensuing studies".

The last plan, which remains in force today, is the $1 / 25$ 000 scale (Capital) Ankara 2023 Master Plan that was approved in 2007. The plan has many strategies related to the valleys, such as creating a continuous urban green system and generating aerial corridors as part of the green system. This is in line with green corridor and greenbelt approaches, and the protection of watersheds and forest areas from local pressures to ensure their continuity. The main strategies are represented with a schema in the plan report. KY and YS codes are proposed for the İmrahor Valley according to the schema, as can be seen in Figure 4. The YS coded areas aim to protect İmrahor Valley and Mogan and Eymir lakes, ensure the continuity of the green system, increase recreational facilities, and remove factories from the valley. The areas coded as KY refer to existing residential areas (Ankara Metropolitan Municipality 2006, p. 619).

Although not denoted in the schema, some of the codes in the 2023 Master Plan allow a certain degree of construction in the valley, with the urban renewal project area (RP), the special project area (SPA), the special

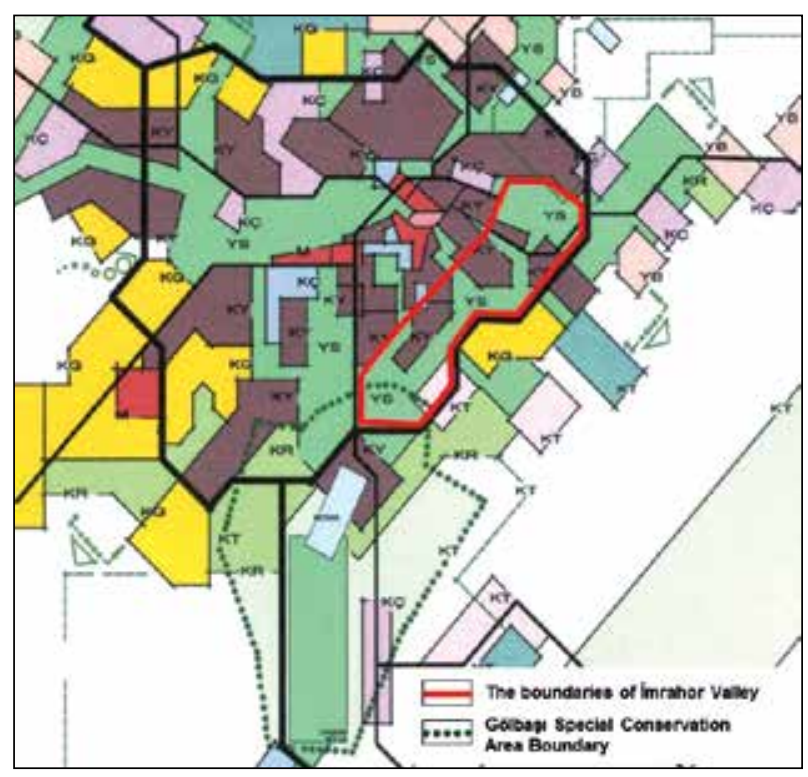

Figure 4. Schema of the Ankara 2023 Master Plan Strategies. Source: Ankara Büyükşehir Belediyesi, 2006, p. 706. 
project district (SPD) (Figure 5), and the existing villages in the valley being defined as urban renewal project areas. Special project areas and districts refer to "residential and/or commercial areas and the required social and technical infrastructure" (Ankara Büyükşehir Belediyesi, 2006; Ersoy, Sutcliffe and Barlas, 2014, p.14).

Following this plan, two major plan revisions were approved in 2013 for İmrahor Valley, based on the 2023 Master Plan proposals. These are the 1/25000 scale (Capital) Ankara 2023 Master Plan Revision, and the 1/5000 scale Karataş-Mühye-İmrahor Master Plan Revision. The 1/25000 scale plan revision involves an area of 624.36 hectares in İmrahor Valley as the new focus of development at the fringe, with a housing density of $155 \mathrm{p} /$ ha for approximately 96,700 people. Tourism and commercial areas are also proposed in the valley plain (Ersoy et al. 2014, p.15).

According to an expert report by Ersoy et al. (2014), the revision plan is, in terms of the protection provided to the ecological system of the valley, inconsistent with the

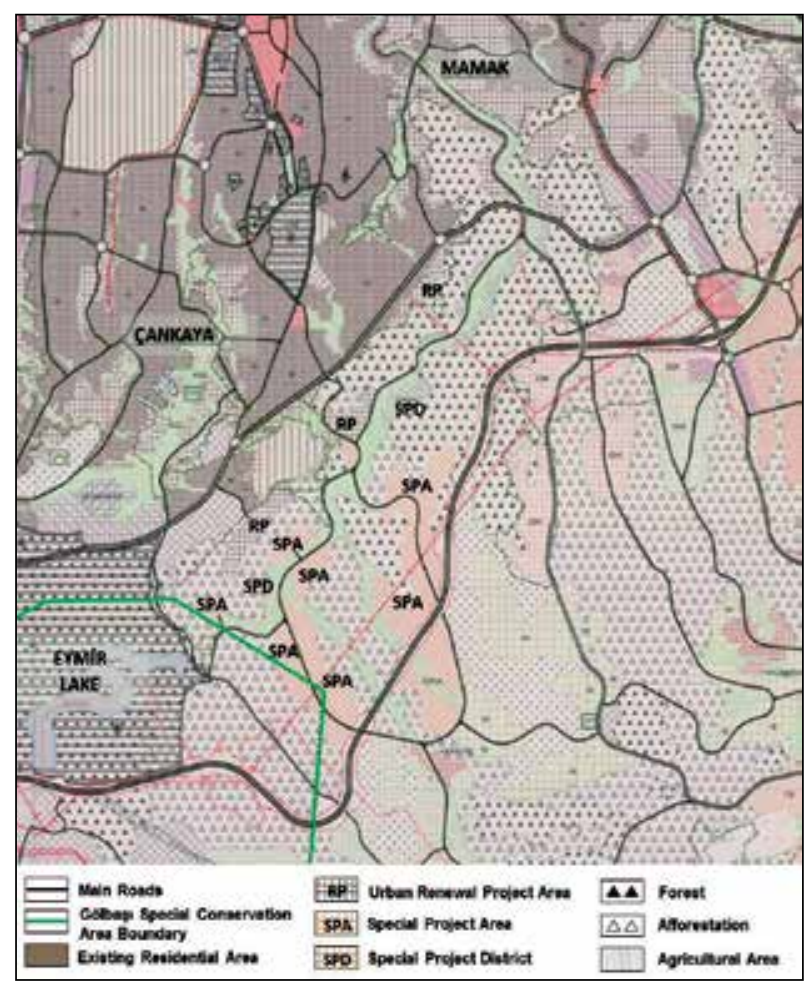

Figure 5. 1/25000 scale Ankara 2023 Master Plan decisions for İmrahor Valley.

Source: Ankara Büyükşehir Belediyesi, 2006. principles and main strategies of the 2023 Master Plan. Furthermore, the new development focus proposed in the revision plan for the valley contradicts all plans made for the city since 1970. It has never been intended to use the valley for urban growth, and creating a new focus of development to this end was not proposed in any of the plans. Furthermore, the housing and population densities and the population projections are criticized as being inappropriate for the fringe area. The expert report also states that tourism and commercial areas are proposed in the valley plain, although the realization of such facilities on the boundary of the flood plain poses a risk for the people involved using these areas. In addition, some parts of the Special Project Areas in the valley (Figure 6) are excluded from the revision plan boundaries, and the subsequent uncertainty created in regard to the land-use decisions of these areas, it has been suggested, constitutes a fragmented approach.

The 1/5000-scale Karataş-Mühye-İmrahor Master Plan Revision of 2013 (Figure 7) and the 1/1000 scale Implementation Plan of 2015 (Figure 8) propose residential,

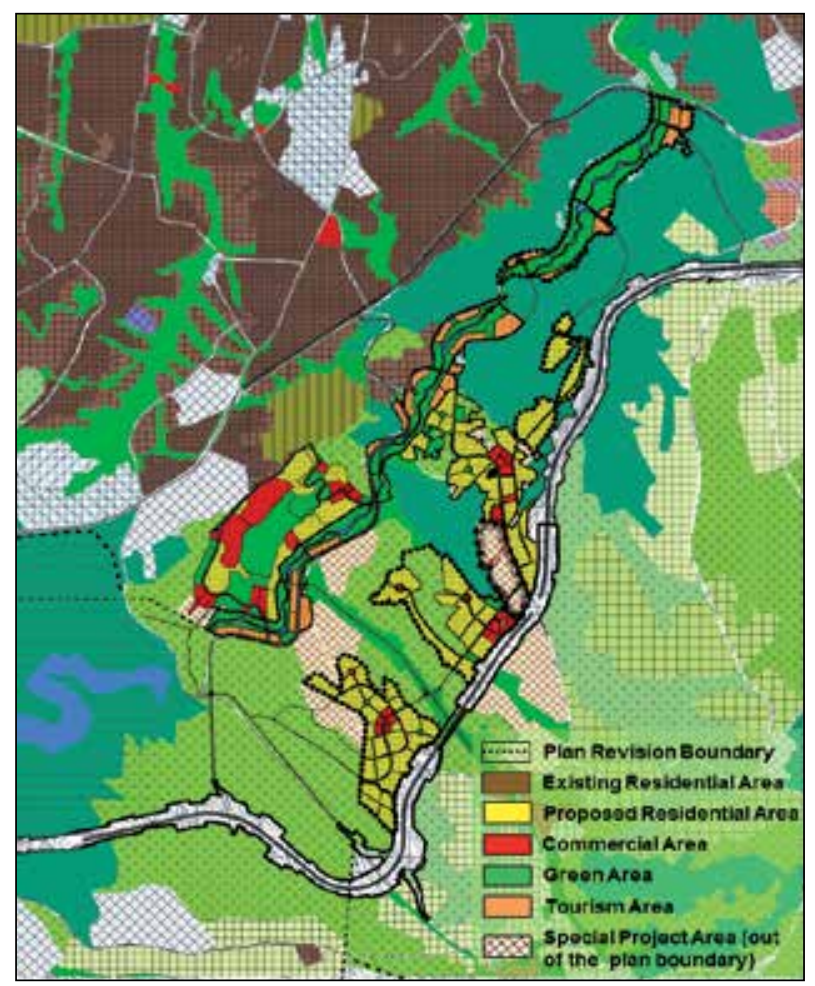

Figure 6. 1/25000 scale Ankara 2023 Master Plan Revision. Source: Ersoy et al. 2014, p.15. 
commercial, tourism and recreational areas along a canal. However, the Chamber of City Planners (2015) stresses that the revision plans and the implementation plan contradict upper-scale plan decisions. According to the Chamber, such measures would increase construction in İmrahor Valley, destroy an important natural habitat, and have a negative effect on the ecosystem. The wind corridor leading to the city center would also be blocked with the implementation of these revisions and plans, and as a result, there would be an increase in air pollution.

After the approval of the plan revisions, the Ankara Metropolitan Municipality signed a contract with a construction firm, leading to development beginning in some parts of the valley in accordance with the revision plans. However, criticisms were raised of the site selection and densities of construction. Despite the specific spatial characteristics of the valley acting as a part of ecologic

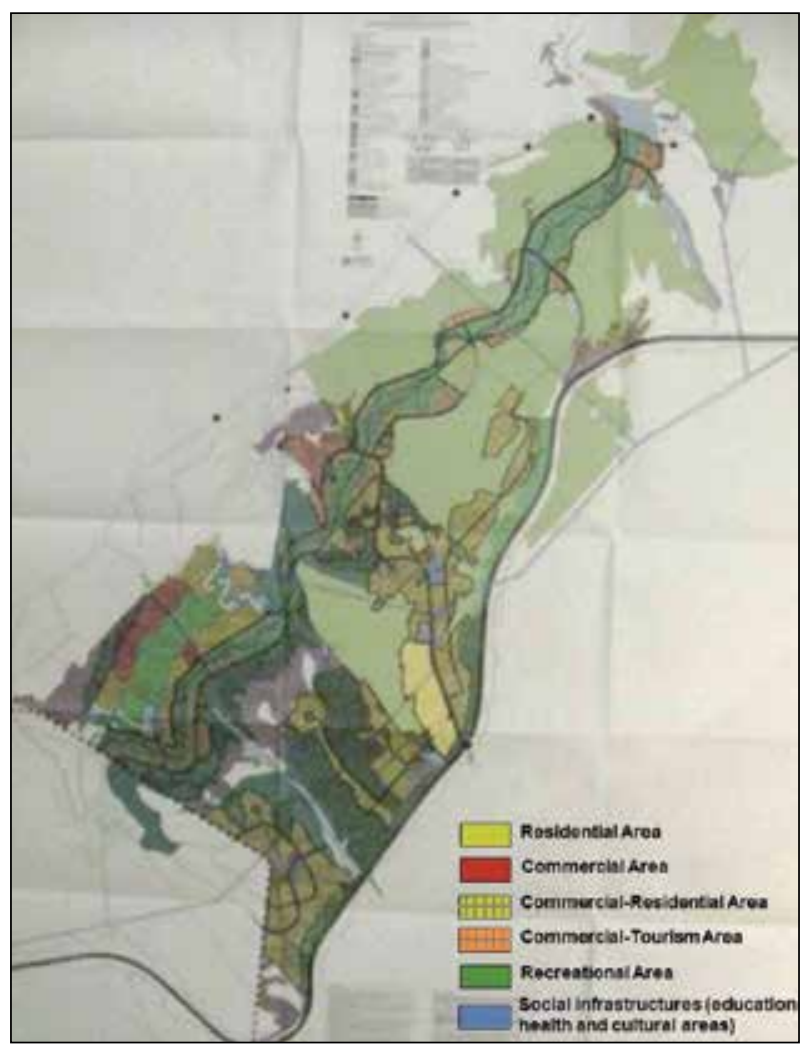

Figure 7. 1/5000-scale Karataş-Mühye-İmrahor Master Plan Revision.

Source: Ersoy et al. 2014, p.16. system, and a wind corridor that has a positive impact on the microclimate of the city, very high-density settlements and commercial areas are being created in the valley (Figures 9, 10, 11).

The recent construction project for the valley is the Housing Development Administration (TOKI)'s, İmrahor Valley Public Garden Project. Recreational facilities, urban gardens, ponds, sports areas, cafeterias, social reinforcements and a museum are proposed in the project. The Housing Development Administration put out the tender for the first stage of the project in February 2019 (TOKI, 2019). However, the Chamber of Architects stresses that the project would create a more built up environment than has been announced to the public. According to the Chamber of Architects, the expansion of construction through this project would increase the ecological damage caused to the valley (Mimarlar Odasi Ankara Şubesi, 2019).

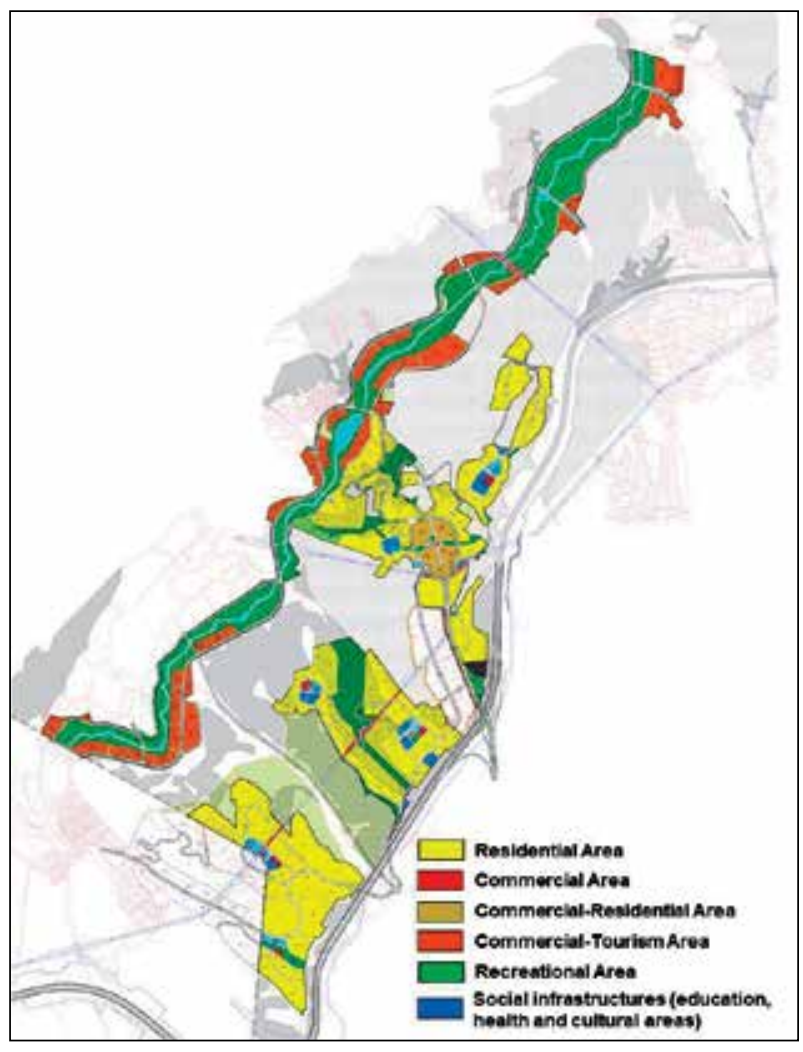

Figure 8. 1/1000-scale Implementation Plan of İmrahor Valley.

Source: Arkitera, February 2015. 


\section{F. Sınacı Özfindık, Changing Characteristics of a Significant Part of the Urban Fringe in Ankara: İmrahor Valley
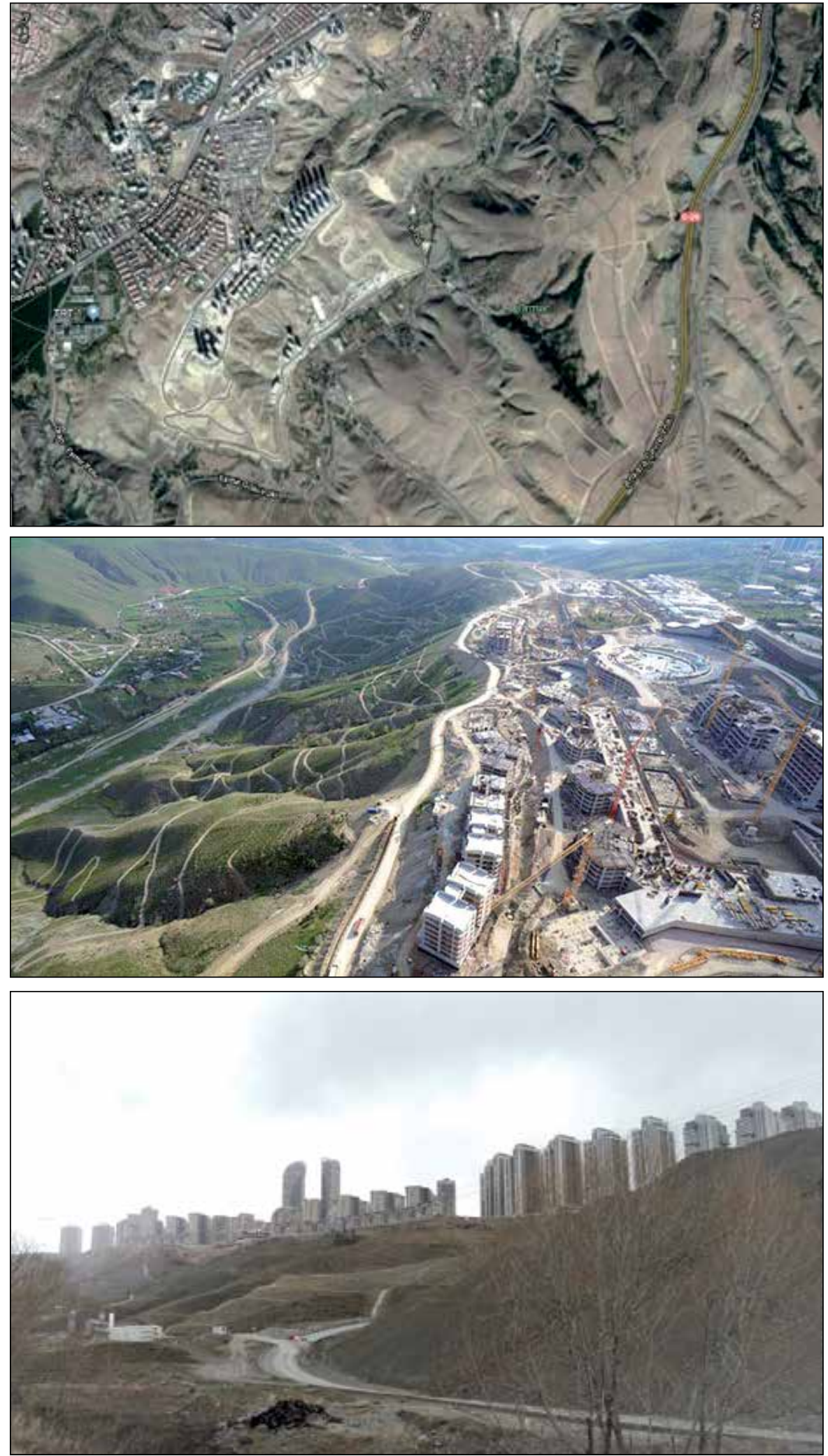

Figure 9. Satellite image of recent construction areas in İmrahor Valley.

Source: Google Maps, June 2019.

Figure 10. Construction areas in İmrahor Valley.

Source: Bilirkişi, February 2016.

Figure 11. Construction areas in İmrahor Valley.

Photograph by Fulya Sinac1 Özfindık, March 2019. 


\section{Results and Recommendations}

Protecting İmrahor valley as a part of green system has been a primary objective since Ankara was first planned in The Jansen Plan (1932) which aimed to conserve all of the valleys around the city. In the Yücel-Uybadin Plan (1956), İmrahor Valley was designated as an forested area, and it was later labeled as a recreation area in the İmrahor Valley Recreation Area Master Plan of 1992. The 1990 Master Plan, 2015 Structural Plan and the 2025 Metropolitan Area Master Plan, all defined the valley as part of the green system of the city and a fringe. All of these plans indicate that İmrahor Valley has long been considered an important part of the green system of the city, and many strategies have been proposed to protect this natural area at the fringe. Forestation was realized in the valley, based on the Greenbelt Forestation Project and the Ankara Forestation Master Plan, until 1997. That said, the İmrahor Valley Explanation Report (2002, p. 19) claims that the natural structure of the valley has been damaged, in part, by the discarded waste of the brick factories and brick kilns, and by the dumping of debris.

Some parts of the valley were opened for development in the 2023 Master Plan, and in Master Plan Revisions, after the mid-2000s. This was driven by new planning decisions for the valley, market forces and speculative pressure, all of which increased tension at the fringe and paved the way for construction. Despite recent partial recreation projects, the valley has been damaged along with many other parts of the fringe. After an analysis of literature and interviews conducted in the İmrahor Valley, the following suggestions are made:

A greenbelt regulation should be enshrined: To ensure the continuity of greenbelt projects, "a greenbelt law" should be drawn up which provides a clear description of the role and objectives of the greenbelt. Development plans should contain no unspecified areas, nor should they encourage partial plans. Ensuring public support is one of the most important factors in ensuring the continuity of the greenbelt, and the people living in Ankara should be encouraged to adopt the idea the valley being protected. Civil Society Organizations also should be involved in this respect. As noted by Bademli (2002, p.9), responsibility-ownership mechanisms should be established for the conservation and management of such areas, and this mechanism should be based on a legal framework. Challenges and opportunities can be identified, strategies and projects can be created and financial resources can be found and used in a reasonable manner through such a mechanism.
The valley should have a legally defined boundary that is set with respect to geographical features: Determining a boundary for the valley has been emphasized by many researchers (Bademli, 2002, p.7; Çulcuoğlu, 1997, p.122; Öztan et.al, 2001, p.25; Çapanoğlu, Bandık, Şahin and Kurttaş, 2002, p.15; İmrahor Vadisi Doğal Sit Alanı Önerisi Açlklama Raporu, 2002, p.19), and is essential for clarifying the areas of responsibility of the many actors in the valley. Analyzing the characteristics of ecosystems is also important in determining the boundary of the valley, while the careful location of entrances to the valley may make it easier to control day-night use and prevent the illegal dumping of debris.

The natural characteristics of the valley should be protected with planning decisions that take into account the valley's relationship with upper-scale ecological systems: The microclimate, topography, wind corridors, water surfaces, vegetation, forests and forested areas in the valley need to be protected to ensure the maintenance of the ecological system. These natural features at the fringe also benefit the environment and increase the quality of life in the city. Elmadağ, İmrahor Valley, Mogan and Eymir lakes, and Gölbaşı are integrated as parts of a water basin. Many studies highlight that such a natural relationship should not be interrupted with urban activities and settlements (İmrahor Vadisi Doğal Sit Alanı Önerisi Açıllama Raporu, 2002, p. 3; Öztan et al., 2001, p.127; Çapanoğlu et al., 2002, p.7; Çulcuoğlu, 1997, p.111), and these studies suggest the valley as having "Natural Protected Area Statute" for this purpose.

As the valley is part of the greenbelt, implementations should include only passive and active green areas that do not destroy the ecological balance: Forestation efforts have affected the valley positively in many respects, such as in preventing erosion and unplanned development. However, the greenbelt efforts have included only the planting of trees in the valley, and have not been used as a planning tool for the creation of a system of recreational areas at the fringe. Accordingly, many recommendations are proposed for İmrahor Valley, the common point of which is the need for recreational facilities in the valley. The İmrahor Valley Explanation Report (2002, p.3) suggests new areas for forestation and places for camping, picnicking and agricultural activities. Öztan et al. (2001, p.128) have made recommendations for sports fields, horse riding, picnic areas, botanical gardens, an arboretum, thematic gardens, multidimensional open places, events and courses to be held in the villages, and 
water gardens, terraces and walking paths in the valley. Koç (2006, p.23) suggests many alternatives for the valley based on a survey, including horse riding, hiking, agricultural recreation for scientific purposes, camping areas, hobby gardens, picnic areas, cultivation, viticulture, paintball and a kite hill, while Çulcuoğlu (1997, p.121) proposes agricultural recreation programs, and steps to encourage biking, jogging and fishing in the valley.

Land policies for state-owned lands should be produced to protect the valley: Legislation should include longterm strategies to prevent land speculation. Policies can be created for the control of state-owned lands at the fringe to sustain the planning, implementation and management process of the greenbelt.

\section{References}

Arkitera. (2015). İmrahor Vadisi İmara Açılıyor, Retrieved from https://www.arkitera.com/haber/imrahor-vadisi-imaraaciliyor/

Ankara Büyükşehir Belediyesi. (2006). 2023 Başkent Ankara Nazım İmar Planı Plan Açıklama Raporu, Etüdler ve Müdahale Biçimleri. Ankara: Ankara Büyükşehir Belediyesi İmar ve Şehircilik Dairesi Başkanlığı

Ankara Metropoliten Alan Nazım Plan Bürosu. (1977). Ankara Nazım Plan Şeması Raporu 1970-1990. Ankara: İmar ve İskan Bakanlığı.

Bademli, R. (2002). İmrahor Vadisi Doğal Sit Alanı Önerisi Ek 2: İmrahor Vadisi'nin Bugünü ve Geleceği [Meeting Notes]. Ankara: Mimarlar Odası.

Bilirkişi: Ankara Güneypark Kentsel Dönüşümü kamu yararına aykırı. (2016, 7 Şubat). Radikal. Retrieved from http://www. radikal.com.tr/cevre/bilirkisi-ankara-guneypark-kentseldonusumu-kamu-yararina-aykiri-1505803/

Cadieux, K.V., Taylor, L. and Bunce, M. F. (2013). Landscape ideology in the Greater Golden Horseshoe Greenbelt Plan: Negotiating Material Landscapes and Abstract Ideals in the city's Countryside. Journal of Rural Studies, 32, 307-319.

Çapanoğlu, İ., Bandık, K.H., Şahin, F. and Kurttaş, E. (2002). Imrahor Vadisi doğal sit alanı önerisi, [Meeting Notes]. Ankara: Mimarlar Odası.

Mimarlar Odası Ankara Şubesi. (2015). Ankara'nın son vadisi Imrahor, Retrieved from http://www.mimarlarodasiankara. org/dosya/imrahor.pdf

Mimarlar Odası Ankara Şubesi. (2019). Millet Bahçesi İmrahor Vadisinde ekolojik travma yaratır. Retrieved from http:// www.mimarlarodasiankara.org/index.php?Did=9976.
Çulcuoğlu, G.K. (1997). Ankara kenti yeşil kuşak çalışmalarının yabancı ülke örnekleri açısından irdelenmesi ve yeşil kuşak sistemi için öneriler. Unpublished Phd Thesis, Ankara University Ankara University Institute of Science and Technology, Ankara.

Department for Communities and Local Government. (2006). Planning policy guidance II: green belts. Retrieved from http://www.knowsley.gov.uk/pdf/PG05_ PlanningPolicyGuidance2-GreenBelts.pdf

Ersoy, M., Sutcliffe, E.B., Barlas, A. (2014). Çankaya İlçesi Yeşilkent (Mühye) ve Karataş Mahalleleri ile Mamak İlçesi Yukarı İmrahor Mahallesi Keşif ve Bilirkişi Raporu, Ankara.

İmrahor Vadisi Doğal Sit Alanı Önerisi Açılama Raporu. (2002). Retrieved from http://www.mimarlarodasiankara. org/index.php?Did=93

Jansen, H. (1937). Ankara İmar Planı. İstanbul: Alaeddin Kıral Basımevi.

Jinjun, M. (2012). The effects of Seoul's greenbelt on the spatial distribution of population and employment and on the real estate market. Annual Regional Sciences, 49, 619-642.

Koç, Y. (2006). Imrahor Vadisinin rekreasyon potansiyelinin saptanmasi. Unpublished Master Thesis, Ankara University Institute of Science and Technology, Ankara.

Öztan, Y., Arslan, M., Perçin, H., Barış, E., Kurum, E. ve Şahin, Ş. (2001). Ankara kenti vadilerinin koruma ve kullanım ilkeleri açısından değerlendirilmesi: İmrahor Vadisi örneği. [Unpublished Tübitak 2001 Project Report]. Ankara.

Şağban, H. (1998). Imrahor Vadisi florası, Unpublished Phd Thesis. Gazi University Graduate School of Natural and Applied Sciences, Department of Biology, Ankara.

Tekeli, İ., Altaban Ö., Güvenç M., Türel A., Günay B. and Bademli R. (1986). Ankara 1985'den 2015'e. Ankara: Ankara Büyükşehir Belediyesi Ego Genel Müdürlüğü.

Toplu Konut İdaresi Başkanlığı (TOKİ). (2019). Proje Tipine Göre Uygulamalar: Ankara İli Imrahor Vadisi. Retrieved from https://www.toki.gov.tr/proje-tipine-goreuygulamalar/ 9445

World Bank. (2008). Exploring urban growth management insights from three cities. Retrieved from http://documents. worldbank.org/curated/en/808871468158072852/pdf/4497 30WP0Box321h1June1200801PUBLIC1.pdf

İmrahor Vadisi Vadi Kalsın. (2015). Yeşil Gazete. Retrieved from https://yesilgazete.org/blog/2019/06/24/imrahorvadisi-vadi-kalsin/

Zhao, P., Bin Lu, B. and Woltjer, J. (2009). Conflicts in urban fringe in the transformation era: an examination of performance of the metropolitan growth management in Beijing. Habitat International, 33, 347-356. 
